\title{
Equal Employment Opportunity Legislation and Policies: the Australian Experience.
}

\author{
Glenda Strachan, John Burgess and Lindy Henderson
}

\begin{abstract}
Purpose. Organisations have to respond to a range of legislative and policy initiatives intended to promote equal employment opportunity for women. This paper analyses the mix of legislation and policies in Australia: anti-discrimination and equal opportunity legislation, equal pay, work and family and managing diversity policies. Approach. Legislation, industrial relations changes and policies relating to pay equity, non-discrimination on the grounds of sex, affirmative action and equal opportunity, including work and family policies and managing diversity approaches are reviewed in the context of changing labour conditions and social trends.

Findings. Organisations are presented with a range of policies from which to choose and the result is variety in the extent and type of equity programs which produce variable outcomes for women in the workplace.

Implications. While this paper deals in particular with Australia, the pattern of multiplicity of approaches is common to other Western countries. As organisations choose among a variety of approaches in implementing an equal opportunity program, the outcomes for women will vary.
\end{abstract}

\section{INTRODUCTION}

Support for employment equity for women at the highest level of government is universal in the developed economies (Wirth 2001, 139-151). The past fifty years have seen a transition from state and organisation supported inequity and discrimination against women workers to policies that support the removal of discrimination and reflect changed social attitudes. In the OECD, the form of these policies depends on prior practice, cultural expectations, political and industrial systems and economic circumstances. A detailed examination of the forces (legislative, judicial, social and industrial) that impact on organisations as they develop and implement equity policies in Australia, serves to highlight the current mixture of messages and directives to which organisations must respond.. Industrial relations practices, workplace relations and anti-discrimination legislation, equal opportunity/affirmative action legislation, and developments in human resource management are considered. Together they trace a trajectory which began with the recognition of the need to redress direct discrimination against women and concludes with a variety of policy approaches. Along the way, measures that promote women's employment opportunities, help businesses to be profitable and support workers who are also carers have been absorbed into the legislative and policy mix. In the end, it can be difficult to talk about organisational equity policies in a country like Australia where the variation in practice between organisations is great with the result that outcomes for women are variable and uncertain.

A series of case studies undertaken in organisations committed to equal opportunity goals that revealed pragmatic but not always consistent responses to legislation, policy guidelines and labour market pressures (Burgess, Henderson and Strachan 2005) prompted this re-examination of the prevailing pressures organisatons face. Hence this article discusses the range of approaches to workplace equity in Australia and examines the likely implications of the current mix. 
In Australia, legislation prohibits discrimination on grounds of sex, pregnancy and marital status and prohibits sexual harassment. Industrial relations legislation contains provisions that promote equal pay and guarantee unpaid parental leave for workers who meet certain employment standards. Provisions that supplement this leave with paid leave and provide a right to return to work after maternity leave on a part-time basis are contained in some industrial agreements or organisational policies. Provisions for leave from work to undertake family caring responsibilities are generally contained in an award or agreement made in an industrial commission between an employer and a trade union but may also be contained in organisational policies. Recent legislation (Workplace Relations Act 2006) has foisted more responsibility on individual firms to negotiate terms of employment rather than relying on trade union negotiations or industry-wide determinations.

Large employers in the private sector are required by law to furnish reports detailing their efforts to ensure equal employment opportunity (EEO) for women, but employers with fewer than 100 employees are exempt. The public sectors of federal and state government operate parallel but separate EEO programs (Bacchi 2000; Burton 1991; Poiner and Wills 1991, 36-56). Although the notions of 'work and family', 'work-life balance' and 'diversity', and variations of these terms, are discussed in public fora such as radio discussion programs and are accepted in the wider community and within organisations, they lack firm definitions.. What an organisation does to promote gender equity is variously determined by its history and ethos, the tightness of its specific labour market and the minimum standards set by legislation. We argue that because employers and employees are faced with a range of options about the way working arrangements are decided and work itself is organised, underpinned in a few instances by legislative minima, outcomes for employment equity are difficult to uncover and unlikely to be consistent among workers and across employers in similar industries. The plethora of policy options provides new challenges for realising gender equity in employment.

\section{Legislation and Policy Development in Australia}

In Australia, industrial decisions designed to redress unequal pay commenced in the late 1960s, anti-discrimination legislation was enacted from 1975 in Commonwealth and state legislatures, affirmative action legislation followed from the mid 1980s, work and family policies emerged in the early 1990s and managing diversity from the late 1990s. The early developments were a response to changing labour market trends and international developments such as United Nations and International Labour Organisation (ILO) conventions and the nascent civil rights and women's movements (Lake 1999 214-230; Grimshaw et al 1994 297-314). The 1980s saw a period of heightened legislative change designed to redress systemic discrimination of women in the workplace, including affirmative action legislation.

In common with other western democracies in the 1980s and 1990s, Australia adopted a neo-liberal approach, 'underpinned by beliefs in the efficacy of the free market' including policies that prioritise deregulation, privatise public sector assets and adopt a new 'orthodoxy of individual responsibility and the "emergency" safety net' (Hancock 1999: 5). Over the past two decades a long-held acceptance of arbitrated collective agreements applying across an industry or occupation has given way to policies and practices that emphasise individual agreements and negotiating 
employment conditions at the workplace level, rather than through a centralised process. In 2006 the dominant discourse is one of individual responsibility ${ }^{1}$ with an emphasis on differential conditions in individual workplaces. It embodies a reluctance to enact policy provisions and minimum conditions in a collective way for the whole labour force or an industry, and offers a reduced safety net of minimum conditions for workers.

Equity provisions are justified largely on the basis that they are good for business: equal opportunity 'boosts a company's profitability and makes incredibly savvy business sense' (EOWA 2006a). This further promotes an individual organisation approach which potentially widens the gap in expectations and outcomes for employees between organisations and even within the one organisation, because there are now few minimum conditions that apply to all workers (Sappey et al 2006, 38-44). The result is that consistency within and between workplaces is increasingly unlikely.

\section{POLICY APPROACHES}

\section{Equal Pay}

In Australia, equal pay decisions have come through the industrial relations system rather than through legislation. Until the 1970s unequal pay rates for women were implemented by the industrial relations system. Indeed, until the Second World War most women received about half the pay of men doing exactly the same job, with a later increase to 75 per cent of the male rate (Ryan and Conlon 1989). Yet in the past four decades the industrial relations system has provided the major route towards pay equity and few issues have been dealt with through the anti-discrimination pathway. In the 1960s, against the backdrop of increasing female labour market participation and the emerging recognition of race and sex discrimination, the peak trade union organisation, the Australian Council of Trade Unions (ACTU), initiated and led successful equal pay cases in the Commonwealth Conciliation and Arbitration Commission in 1969 and 1972. Different pay rates for women and men doing the same job were no longer allowed, so that many women were accorded pay equity with men (Ryan and Conlon 1989: 162). Largely as a result of these decisions, Australia's female to male earnings ratio increased faster in the 1970s than that of any other country, from around 0.60 to 0.80 in six years (Burgess et al 1998).

An attempt to widen the concept to 'work of equal value' (comparable worth) in 1986 was unsuccessful (Rafferty 1994: 467). However, the women's movement and trade unions continued to press for a re-examination and new wage fixing principles were adopted in 2000 in the state of New South Wales. The crux of these is that 'assessment of the work, skill and responsibility...is to be approached on a gender

\footnotetext{
${ }^{1}$ The pace quickened with the election of a federal conservative government in 1996 and the introduction of workplace or enterprise bargaining (Workplace Relations Act 1996). More recently a conservative majority in both houses of federal parliament facilitated the introduction widespread changes in industrial relations legislation, removing all but the most basic protection for workers and reinforcing the existing emphasis on individual as opposed to collective workplace agreements (Workplace Relations Amendment (Work Choices) Act 2005). As most of these agreements are confidential, and there are few legislative minima, changes will occur on an individual basis and the outcomes for women workers will be hard to discover.
} 
neutral basis and in the absence of assumptions based on gender' (IRC NSW 2000). Other states have held similar inquiries and a small number of cases have resulted in wage increases for specific groups of workers in predominantly female occupations (Queensland IRC 2002; Victorian Pay Equity Working Party 2005; IRC NSW 2002 and 2006; Teece 2002).

In 2005 women's wages were 0.85 of men's (full-time adult ordinary time earnings) (ABS 2005). The resilience of the pay gap over time suggests 'multiple and deeply entrenched causal factors' within and outside the labour market including occupational segregation, undervaluation of traditional women's work and organisational culture and practice, and the gendered division of domestic labour (Whitehouse 2004). The centralised industrial relations system has been a crucial player in establishing the principle of equal pay in Australia and addressing equal pay issues. Yet the essential framework of permanent tribunals setting industry/occupation wide awards of minimum conditions, which applied to all workers in the specified job category and industry, has been progressively removed since the late 1980s (Peetz 2006, 48-81). As industry-wide occupational classifications become less important and workplace or individual agreements become paramount, so the old industrial relations framework is being dismantled. The increase in individual and confidential agreements, with few minimum legislated standards (Sappey et al 2006, 22-37), may undermine pay equity between individuals doing the same job in an organisation, and will certainly promote inequity across occupations, thereby increasing the chances of gender inequity (Hammond 2006). Indeed, 'it is not fanciful to suggest that the door has been opened for employers to discriminate between male and female workers...on the basis of their hunches about what different individuals would be prepared to work for...despite thirty years of active campaigning and community consciousness raising to eliminate precisely this behaviour' (Probert 2005, 3).

\section{Anti-Discrimination Legislation}

The Australian Sex Discrimination Act 1984 which follows the ILO Convention 111 of 1958 (ratified in 1973) makes it unlawful to discriminate on the grounds of sex, marital status or pregnancy and prohibits sexual harassment. The Act recognises the phenomenon of structural or indirect discrimination which 'arises from the fact that organisational norms, rules and procedures, used to determine the allocation of positions and benefits, have generally been designed...around the behaviour patterns of the historically dominant group in public life (Anglo-Australian, able-bodied, heterosexual males)' (Hunter 1992: 5). This has enabled groups of women to pursue remedies. A celebrated case involved women workers challenging the 'last on, first off' rule for redundancies at a steel works which had refused over many years to employ women in operational jobs, hence women had a shorter length of employment (Scutt 1990: 61-62). In recent court cases, however, there has been a 'refusal to acknowledge the fact that male and female employees are generally not similarly situated' in relation to family responsibilities (Adams 2005: 34). This suggests that the legislation does not protect workers with family responsibilities from indirect discrimination.

While important in resolving some instances of discrimination, taking a case which meets the terms of the legislation can be difficult (Scutt 1990: 76; Charlesworth et al 2002). This legislation by its very nature must produce individual and ad hoc solutions which do not alter the widespread patterns of employment discrimination. 
The legislation's 'foundational assumption...is that society's rules are generally functioning fairly, but that a particular attitude produces an unfair behaviour called "discrimination" which requires "intervention", (Bacchi 1996: 18). Again, the individual's situation is the key to this process. The legislation does, however, provide a baseline in guarding against overt discrimination and its principles are widely known (if not always completely understood) in the community.

\section{Equal Employment Opportunity Legislation}

Legislative remedies that do not rely on individual cases of discrimination were enacted in the mid 1980s. The legislation recognised the historic and extant systemic disadvantage of women in employment: 'Affirmative Action' is based on recognition and acceptance of the fact that it is not sufficient to make specific acts of discrimination unlawful. Further steps are needed to relieve the effects of past discrimination, to eliminate present discrimination and to ensure that future discrimination does not occur' (Department of Prime Minister and Cabinet 1984: 8). The principles of the legislation recognised that 'certain specific steps aimed at promoting equality in employment for women need to be undertaken to eliminate existing disadvantages and ensure that the employment system operates in a manner that is fair and equal to all employees and applicants' (Ronalds 1988: 12). The Affirmative Action (Equal Opportunity for Women) Act 1986 was the principal law in this area. Employers with more than one hundred employees were required to institute an affirmative action program 'based on a systematic and planned approach to the identification of existing structural barriers which prevent or inhibit women from fully and equally participating in the workforce' (Ronalds 1988: 12-13).

The 1986 Act was replaced by the Equal Opportunity for Women in the Workplace Act 1999 (EOWW Act). The overall goals of the two Acts are similar: to promote the principle that employment for women should be dealt with on the basis of merit, to promote elimination of discrimination and provision of equal opportunity for women, and to foster workplace consultation between employers and employees on these issues (EOWW Act Section 2A). Underlying this legislation is the dual recognition of benefits for business and the economy together with a commitment to social justice. Neither Act defines equal opportunity itself but An 'Equal Opportunity for Women in the Workplace' program is interpreted as appropriate action to eliminate discrimination and contribute to the achievement of equal opportunity for women (EOWW Act Section 3). The 1999 legislation requires organisations to develop a program by preparing a work place profile, analysing the equity issues for women, identifying priority issues, taking action to address them and evaluating the effectiveness of the actions (EOWA 2006b). Reporting has been required on an annual basis (although this can be waived under certain circumstances if the organisation can demonstrate consistent good practice and will change to biennial reporting for many organisations from 2007) (EOWA 2007a). Penalties for noncompliance under both Acts have been weak: a non-compliant organisation can be named in parliament and is ineligible to tender for government contracts and industry assistance (EOWA 2007b). The focus of the Acts is individual enterprise responsibility as opposed to legislative and economy wide standards in order to achieve equity goals (Strachan, Burgess and Sullivan 2004).

The affirmative action project in Australia has taken the liberal approach of achieving equality of treatment rather the radical approach of equality of outcomes (as in the use of 
quotas) (Thornton 1990, 2001). Critics argue that if equal opportunity requires men and women to be treated the same, the outcome will be that women are offered equality on male terms and are required to comply with male centred norms and patterns and this may reinforce the idea that women's difference equals disadvantage (Bercusson and Dickens 1996: 16). Thus the male norm is not challenged (see Webb 1997):

Equal treatment disadvantages women by ignoring the structural barriers which limit job opportunities and underestimates the practical difficulties and cultural expectations which deter women from combining employment and domestic responsibility (Neave 1992: 806-07).

However, the danger in acknowledging structural barriers and in protecting women's different roles and responsibilities is that the law may perpetuate stereotypes (Bercusson and Dickens 1996: 18). Liff and Cameron (1997: 35-36) believe that the consequences of the special treatment which women may require to allow them to compete in the workplace, or even the view that women are the problem because they do not fit into existing practices, are that 'men do not need to be involved in equality measures and that there is no need to change organisational structures'. Thus measures which reinforce the premise that women have primary responsibility for childcare, such as enhanced maternity leave or part-time work, may be problematic. Nevertheless, this limited affirmative action agenda has largely been accepted (for example Bacchi 1999) as preferable to a lack of action even though the beneficiaries of the legislation were seen as a limited group of white Anglo-Celtic women with education, that is women already 'in the system', while of women in sex-segregated areas of the labour market were not addressed specifically (Bacchi 1990: 1)

\section{The Business Case}

Since 2000, the Equal Opportunity for Women in the Workplace Agency (EOWA) has had responsibility for administering the EOWW Act and has adopted a pragmatic approach that emphasises the businesss advantages of EEO for women. It uses slogans such as 'women + men $=$ success' to promote its programs (EOWA 2006c). ILO documentation accepts the business case as enhancing the capacity to attract a broader range of quality employees in a competitive job market, reduced staff turnover, less absenteeism and lateness, enhanced staff performance and motivation and improved productivity, a competitive edge and innovation contributing to improved effectiveness (ILO 2004s). EOWA in Australia has listed the benefits of workplace programs to include enhanced attraction and retention of the best talent, increased productivity and innovation, enhanced management style, gain in the number of female customers and reduction in the risk of discrimination and harassment law suits (EOWA 2006d). EOWA also states that 'the economic status of traditionally disadvantaged people is improved' (EOWA 2006e) and thus a social justice dimension sits somewhat uneasily alongside the promise of enhanced business outcomes (see Liff 1999; Dickens 1999).

However,by spelling out the issues which it considers comprise the parameters of EEO for women, EOWA gives employers and their human resource (HR) managers a broad outline of what comprises equality at work. This outline revolves around individual rights to protection from discriminatory treatment and the perceived advantages which employers and employees obtain from largely unspecified equal opportunity policies and practices. The legislation and reporting procedure may make managers aware of issues for women in employment and prompt them to action. On the other hand, penalties for non-compliance are weak. A proportion of organisations 
respond with programs that address equity issues in a minimal fashion (French and Strachan 2007; Strachan and Burgess 2000). Since management in each organisation is responsible for developing its own program, promoting the business case may be an effective strategy. In the end, the implementation of EEO principles presumes good corporate citizenship, the effective participation of women employees in its development, and a process of shared goals and participation.

\section{Work and Family Policies}

Affirmative action and equal opportunity legislation programs take no explicit account of life outside work and its interaction with paid employment (for example Bacchi 1990: 169) and assume a full-time male worker as the norm. As Thornton (1995: 8) noted, 'the legislative endeavours carefully cordon off the domestic sphere from scrutiny'. Work and family policies, not underpinned by legislation, entered the equal opportunity discourse in the 1990s. They present an apparently non-gendered face to employment equity and can be seen to address this criticism. Broader terms such as 'work/life balance' signify a wider perspective of non-working life than family care. In contrast to affirmative action programs which do not seek explicitly to change the organisation of work or the interface between paid work and private life, work and family policies focus on this interface and a potential change in the balance of paid work and caring between women and men. A number of writers (for example Lewis 1997) have argued that 'a more pro-active approach is needed, based on the view that it is organizations not women who have the problems' (Liff and Cameron 1997: 36). Bercusson and Dickens (1996: 21) propose that provisions targeted at men, such as paternity leave, "could help foster a greater sharing of social and occupational responsibilities as between men and women and help challenge the "male norm" in the organisation of paid work' and this approach potentially may offer more in terms of gender equality.

There is now a vast amount of discussion about this topic in Australia (for example, see Charlesworth, Campbell and Probert 2002; Goward et al 2005). While this debate is premised on radical changes to work and caring patterns in the community the term 'work and family' has been appropriated to refer to a multitude of workplace issues. In Australia as elsewhere there is no single definition of the family friendly workplace or work-life balance, but there is a broad consensus of desirable policies and practices (Burgess and Strachan 2005; OECD 2002; Eaton 2003; Thornthwaite 2002, Strachan and Burgess 1998). In the Australian context 'work and family' has been used to justify significant workplace changes which may or may not promote sharing of responsibilities or make the combination of responsibilities easier to bear. While recognising that individuals have to combine both public and private parts of their lives, the private burden of family care remains greater for women who 'have continued to carry the greater responsibility for caring and other unpaid work' (Goward et al 2005: ix) and therefore these policies have greater relevance for women whose family commitments necessitate temporal flexibility The central issues for women who are carers revolve around a limited agenda that allows enough flexibility to take leave from paid work to fulfil family responsibilities without jeopardising job security or other opportunities at work. Table 1 outlines a suggested list of provisions.

Table 1: Checklist of arrangements for work-family balance

\begin{tabular}{|l|l|}
\hline Type of arrangement & Comment \\
\hline
\end{tabular}




\begin{tabular}{|l|l|}
\hline Income security & Rates of pay, having a regular and secure income \\
\hline Employment security & $\begin{array}{l}\text { Predictable hours, ongoing employment, able to take } \\
\text { career breaks, able to undertake financial commitments }\end{array}$ \\
\hline Access to care arrangements & Affordable, accessible childcare, other care (e.g. elder) \\
\hline Access to flexible leave & $\begin{array}{l}\text { Standard leave entitlements, parental leave, switch } \\
\text { between types of leave, leave in emergencies }\end{array}$ \\
\hline $\begin{array}{l}\text { Flexible working time } \\
\text { arrangements }\end{array}$ & $\begin{array}{l}\text { Able to vary hours, start/finish times, flextime, job } \\
\text { share or other innovations over the life-course }\end{array}$ \\
\hline $\begin{array}{l}\text { Control over unfriendly } \\
\text { working hours }\end{array}$ & $\begin{array}{l}\text { Vary or avoid long, unpredictable, unsociable working } \\
\text { hours or changes at short notice }\end{array}$ \\
\hline $\begin{array}{l}\text { Access to training and } \\
\text { career path }\end{array}$ & $\begin{array}{l}\text { Includes access for part-time workers and career } \\
\text { breaks }\end{array}$ \\
\hline $\begin{array}{l}\text { Innovative work } \\
\text { arrangements }\end{array}$ & Study leave, home work, telecommute etc. \\
\hline
\end{tabular}

Source: Burgess and Strachan 2005.

There is a risk that 'flexible' work patterns simply means deregulated working hours and conditions. These 'flexible' conditions can include longer working days, a longer working week, and increased numbers of part-time and casual (temporary) workers who have little access to full-time or permanent work, employment benefits or career path but do not preclude arrangements that enable work and family balance (Burgess and Strachan 1999, Burgess et al 2005). The question of choice and power in the employment relationship is a critical determinant of which arrangements are beneficial to employees in managing work and family commitments. Changes to the industrial relations system in Australia in 2006 that promote individual bargaining mean that temporal flexibility is especially dependent on the strength of the employee's voice and the state of the particular labour market.

\section{Managing Diversity Policies}

The term 'managing diversity' (MD) came to Australia from the USA as a management strategy. In the USA, the popularity of MD reflects a search by organisations for an alternative to the contentious affirmative action model and as a way to broaden what was seen as a narrow agenda that concentrated on hiring to include issues of retention, integration and career development (Agocs and Burr 1996: 34). It conveniently by-passes the conflicting arguments about affirmative action, equal treatment and equal outcomes by focussing on the individual employee and his/her needs. Diversity of sex, age, background, race, disability, personality and workstyle are typically included on 'the premise that harnessing these differences will create a productive environment in which everybody feels valued, where their talents are being fully utilized and in which organizational goals are met' (Kandola and Fullerton 1994: 8). This description denies systemic discrimination suffered by specific groups in the labour market. On the other hand, some recent work advocates a definition of diversity that:

emphasizes intergroup interaction and is inclusive of power differences, rather than focusing on individual differences. This means explicitly acknowledging the role played by past discrimination and oppression in 
producing socially marginalized groups today (Prasad, Pringle and Konrad 2006, 8).

Kirton and Greene (2005: 123) summarise the variety of approaches in the literature describing MD as 'an evolutionary step from equality'; 'a sophistication of the equality approach'; 'a repackaging of equality'; 'a sanitized, politically unthreatening and market-oriented notion'; a policy that allows employers 'to avoid actively fighting discrimination'. Managing Diversity thus leaves organisations with a wide, even confusing, choice of directions and rationales.

The MD approach supplants EEO by stressing the convergence of the organisation's objectives with those of the individual worker, and to this extent it conforms to the business case. According to EOWA, Australian organisations need to move from the concept of 'diversity as solely a social justice issue to diversity as a competitive business strategy' (EOWA 2007c), justifying the premise that MD can have a positive role in establishing work place equity. A range of activities may be involved in managing diversity, such as:

ensuring that HRM systems are bias-free, facilitating higher career involvement of women, promoting knowledge and acceptance of cultural differences, ensuring involvement in education....and dealing with employees' resistance to diversity (De Cieri and Kramar 2005: 15).

Kramar (1998: 141) asserts that the stimulus for MD will be the continuing search for organisational effectiveness, devoid of the moral or broad economic arguments that underpinned AA while Agocs and Burr (1996) see it as an approach to management rather than to equity. Singh et al (2002: 2) characterise organisational diversity initiatives as 'a managerial philosophy which aims to value workforce diversity in all its forms in order to generate benefits for the organisation's various stakeholders and therefore improve corporate competitiveness by enhancement of organisational performance'. In this characterisation MD is a way of managing staff and the MD program is therefore dependent on business conditions. It also allows organisations to ignore systemic disadvantage. Sinclair assesses the situation in Australia: 'the development of a diversity discourse in management practice has subordinated... [equality of treatment and opportunity] ideals' (Sinclair 2006: 511). Bacchi (2000) argues that the MD program in the public sector attempts to hide inequalities under the umbrella of 'difference' and to by-pass fundamental equity programs and social policy objectives. This entails leaving equity programs to business and reducing the extent of external scrutiny of business employment practices, evident in the current EEO legislation. While EEO has many gaps, it does force (large) businesses to articulate a gender equity agenda and to report on progress with respect to this agenda. At a fundamental level, MD treats difference as a virtue and proclaims differences in employment practices and employment outcomes as a virtue. The outcome may be beneficial to some or all employees in an organisation, but may also disguise discriminatory workplace outcomes.

Given the variety of approaches, in some ways an organisation can shape a MD policy as almost anything it wants, but we have argued that MD will have its own range of variations in Australia as employers redefine it in the context of past and present legislation and practice. We predicted that responses would include negating systemic discrimination or rebadging AA or EEO programs as MD programs, and sanitizing the equality approach (Strachan, Burgess and Sullivan 2004). 


\section{OVERVIEW OF THE EQUITY POLICY MIX}

The legislation and policies have been propelled by a mixed rationale of social justice (including acceptance of international standards in the form of ILO conventions) and business benefits (see table 2). In recent years the legislation has been promoted on the basis that it is good for business. Work and family or work/life policies are harder to assess, since they are specific to the work place and work role, and can serve the needs of employers and/or employees.. MD is an initiative promoted as good for business, and the assumption that it is 'family friendly' is largely untested (Strachan, Burgess and Sullivan 2004).

Table 2: Schema of Equity Approaches

\begin{tabular}{|l|l|l|l|l|l|}
\hline & Equal Pay & $\begin{array}{l}\text { Anti- } \\
\text { discriminati } \\
\text { on }\end{array}$ & $\begin{array}{l}\text { Affirmative } \\
\text { Action / } \\
\text { EEO }\end{array}$ & $\begin{array}{l}\text { Work and } \\
\text { Family }\end{array}$ & $\begin{array}{l}\text { Managing } \\
\text { Diversity }\end{array}$ \\
\hline Rationale & $\begin{array}{l}\text { Social } \\
\text { justice }\end{array}$ & $\begin{array}{l}\text { Social } \\
\text { justice }\end{array}$ & $\begin{array}{l}\text { Social } \\
\text { justice \& } \\
\text { business } \\
\text { case }\end{array}$ & $\begin{array}{l}\text { Social } \\
\text { justice \& \& } \\
\text { business } \\
\text { case }\end{array}$ & $\begin{array}{l}\text { Business } \\
\text { case }\end{array}$ \\
\hline $\begin{array}{l}\text { Recognition } \\
\text { of systemic } \\
\text { discriminati } \\
\text { on yes }\end{array}$ & no & yes & No & no \\
\hline $\begin{array}{l}\text { Change } \\
\text { work } \\
\text { practices? }\end{array}$ & no & no & no & yes & yes \\
\hline
\end{tabular}

A pattern can be seen in the development over time of equal pay policies, affirmative action, equal opportunity, and managing diversity trends in Australia. Early attempts to eliminate discrimination were followed by a legislated EEO program of setting, monitoring and achieving gender equity outcomes; currently business is left to manage its gender equity programs with less government intrusion. The deletion of the step specifying goals and targets in the 1999 EOWW Act reduced the emphasis on outcomes, and other changes have allowed greater management discretion in the development of equity policies. The recent change to biennial rather than annual reporting is another step along this path (EOWA 2007a). It is quite clear when sampling annual reports to the EOWA that many organisations' reports meet the minimum requirements of the Act and no more. Overall, most of their HR policies do not display an understanding of EEO or MD issues (French and Strachan 2007).

From the mid-1990s, and increasingly, the dominant discourse in employment is about combining paid work and family care. These issues have gained widespread public recognition in Australia and have resulted in some minimum conditions (for example, unpaid parental leave and use of sick leave to care for family members), largely through decisions of the industrial relations commissions. Yet implementing these in a cohesive way to the benefit of employees is reliant on an EEO plan within each organisation. The discourse has moved from being one of EEO that is based on an analysis of gendered workplace discrimination to that of 'work and family' and 'family-friendly' organisations - a notion that is hard to disagree with and one that is more acceptable to a conservative government analysis of women and society 
(Ostenfeld and Strachan, 1999). In Australia the language of choice, flexibility and work-life balance has largely replaced earlier discourses that involved employment equity and even earlier ones of positive discrimination or affirmative action (Strachan, Burgess and Sullivan 2004; Bacchi 2000).

In Australia affirmative action/EEO legislation sits firmly on a base of recognition of historic and systemic discrimination against women. In contrast, work and family policies and MD policies do not necessarily recognise any groups, including women, who still face systemic discrimination and disadvantage. Instead, these policies focus on individual differences. While work and family policies explicitly recognise that workers have to combine paid employment with other responsibilities it does so with a non-gendered face which, it has been argued, defies reality in Australia (Goward et al 2005).

Managing Diversity as a workplace policy has similarities with family friendly work policies in a number of respects. Both are voluntary and rely on managers to determine policies and practices. There are no objective standards by which to measure the success of different programs, and indeed what constitutes a successful program is unclear. In an era of increasing emphasis on quality assurance of products and services, it is concerning that these policies come without any measurable goals and objectives. The EEO/AA legislation in Australia emphasised collection of data on which to base programs and report to the community; organisations could develop performance indicators to measure progress towards a defined goal and employment data and policy outlines were publicly available. Both MD and work and family policies are individualist: differences in family arrangements support the family friendly work agenda while differences across the workforce support the MD agenda.

Anti-discrimination and affirmative action/EEO legislation do not seek to change work practices explicitly except to remove discrimination and to promote equality of opportunity. Women are to receive the same conditions and opportunities as men. Work and family policies may change some features of the organisation of work as they include temporal flexibility and recognise the mix of demands that employees face. However, there are major questions over how much control employees have over their own working arrangements and this varies between and within workplaces. In addition, some of this flexibility is gained alongside increasing hours for full-time workers (Watson et al 2003: 84-92) so the practices can be pulling in opposite directions. The business case may or may not promote equity or work/life balance, however defined. MD promises cultural changes at work, but each enterprise must set its own goals and work within its existing norms: this raises the likelihood of accepting the status quo as an adequate response.

\section{THE CHOICES FOR ORGANISATIONS}

In Australia, organisations are made aware that they must not discriminate and have to take action to prevent sexual harassment. Otherwise, they face an array of policy approaches promoted by a variety of government agencies and debated in the popular press. In the absence of compulsory practices or specified endpoints, and with satisfactory work-family balance outcomes largely undefined and untested, organisations are left to make their own judgements about what is equitable for employees and profitable for business. It is not surprising that organisations are really 
only certain about what to do when policies are clearly spelt out in legislation (Liff 1997; Strachan, Burgess and Sullivan 2004).

Like many other OECD countries, Australia now presents a complex mix of legislation and policies related to gender equity. Prior to the 1970s employment was characterised by direct discrimination against women in remuneration and availability of training and jobs. From this position of overt discrimination, legislation from the 1970s recognised direct and subsequently indirect discrimination and put in place systems through which individuals could process a claim of discrimination. Since the mid-1980s there has been recognition that pro-active policies and practices are needed within organisations if women are to achieve equitable employment outcomes. These policies, while they are in some instances promoted by the government, have only weak legislative underpinning and are not necessarily observed in many organisations.

Organisations are able to choose the policies and practices that they believe are appropriate to their particular business situations, and the extent to which they will implement them. This might include. attention to workers' preferences in relation to individual work arrangements and career paths; emphasis on recruiting and/or training women in non-traditional roles; increasing 'flexibility' in the span of hours worked, length of shifts and other temporal arrangements; or any one of a number of other priorities. Organisations can portray many different policies and practices as related to EEO without assessing outcomes against specified criteria or undertaking any measurement of change. Organisational equity policies and practices are determined by ad hoc business and labour force demands which may be coloured by the organisation's own ethics and values (Burgess, Henderson and Strachan 2005).

The emphasis on individual organisation choice is in line with an increased Australian Government emphasis on individual agreements, and away from collective, industrywide norms, in the industrial relations system. This has been accompanied by reduced legislative minimum employment standards. The result is that working conditions and arrangements, including gender equity, must be negotiated or fought for at the level of the workplace or individual employee with the back-up of only minimal legislated labour standards together with anti-discrimination legislation and that organisations are left with many choices and little guidance in developing employment policies and practices. The need for government agencies, trade unions and industry organisations to help employers and employees arrive at consistent and equitable outcomes is pressing.

\section{Acknowledgements}

This research has been funded by an Australian Research Council Grant. The authors would like to thank Dr Hazel Conley, the editor of this issue, and the anonymous referees for their insightful comments on an earlier draft of the paper.

\section{$\underline{\text { References }}$}

ABS (Australian Bureau of Statistics) (2005), Average Weekly Earnings. Catalogue No. 6302.0, November.

Adams, K. Lee (2005), "Indirect discrimination and the worker-carer: it's just not working", Law in Context, vol. 23, no. 1, 18-44. 
Agocs, Carol and Catherine Burr (1996), "Employment Equity, Affirmative Action and Managing Diversity: Assessing the Differences", International Journal of Manpower, vol.17, no. 4/5, 30-45.

Bacchi, Carol (2000), "The Seesaw Effect: Down Goes Affirmative Action, Up Comes Workplace Diversity", Journal of Interdisciplinary Gender Studies, vol. 5, no 2, 64-83.

Bacchi, Carol (1999), “'Rolling back the state'? Feminism, theory and policy”, in Linda Hancock (ed.) Women, Public Policy and the State, Macmillan, Melbourne, 54- 69.

Bacchi, Carol (1990), Same Difference: Feminism and Sexual Difference, Allen and Unwin, Sydney.

Bacchi, Carol (1996), The Politics of Affirmative Action: “Women”, Equality and Category Politics, Sage, London.

Bercussen, Brian and Linda Dickens (1996), Equal Opportunities and Collective Bargaining in Europe: 1. Defining the Issues, European Foundation for the Improvement of Living and Working Conditions, Dublin.

Burgess, John and Glenda Strachan (1999), "The Expansion of Non-Standard Employment in Australia and the Extension of Employer's Control", on Alan Felstead and Nick Jewson (eds) Global Trends in Flexible Labour, Macmillan Business, London, 121-140.

Burgess, John, Nic Croce, Richard Denniss, Roy Green, and Glenda Strachan (1998), Statement by the Employment Studies Centre, University of Newcastle, to NSW Pay Equity Inquiry.

Burgess, John, Lindy Henderson, and Glenda Strachan (2005), "Women workers in male dominated manufacturing organisations: contrasting workplace studies from Australia", Management Revue, vol. 16, no. 4, 458-475.

Burgess, John and Glenda Strachan (2005), "Integrating Work and Family Responsibilities: Policies for Lifting women's labour activity rates," Just Policy, no. 35, 5-12.

Burton, Clare (1991), The Promise and the Price: The struggle for equal opportunity in women's employment, Allen and Unwin, Sydney.

Charlesworth, Sara, Iain Campbell, I. and Belinda Probert with June Allan and Leonie Morgan (2002), "Balancing Work and Family Responsibilities: Policy Implementation Options", Report for the Victorian Departments of Premier and Cabinet and Innovation, Industry and Regional Development, Centre for Applied Social Research, RMIT University, Melbourne.

DeCieri, Helen and Robin Kramar (2005), Human resource management in Australia: Strategy, people, performance, $(2$ nd $\mathrm{ed}$.). McGraw-Hill, Macquarie Park, NSW.

Department of the Prime Minister and Cabinet (1984), Affirmative Action for Women: Volume 1: A policy discussion paper, Australian Government Publishing Service,Canberra.

Dickens, Linda (1999), "Beyond the business case: A three-pronged approach to equality action", Human Resource Management Journal, vol. 9, no.1, 9-19.

Eaton, Susan. C. (2003), "If you can use them: flexibility policies, organisational commitment and perceived performance", Industrial Relations, vol. 42, no. 2, 145-167.

EOWA (Equal Opportunity for Women in the Workplace Agency) (2007a), "Important Reporting Update", http://www.eeo.gov.au/Reporting_And_Compliance_LandingPage.asp Accessed 1 February. 
EOWA (2007b), "What Happens if my Report does not Comply?" http://www.eeo.gov.au/Reporting_And_Compliance/What_Happens_if_my_R eport_does_not_Comply.asp Accessed 1 February.

EOWA (2007c), "Visions for the Future", http://www.eowa.gov.au/about_equal_opportunity/key_agenda_items/women _in_decision_making_roles/vision_for_the future.asp Accessed 1 February.

EOWA (2006a), "Why EO makes business sense", http://www.eeo.gov.au/About_Equal_Opportunity/Why_EO_Makes_Business Sense.asp Accessed 17 July.

EOWA (2006b), "What is a Workplace Program?" http://www.eeo.gov.au/Developing_a_Workplace_Program/What_is_a_Work place_Program.asp Accessed 4 August.

EOWA (2006c), "EOWA Homepage", http://www.eowa.gov.au/eowa Accessed 4 August.

EOWA (2006d), "Five Ways EO Boosts Profitability", http://www.eeo.gov.au/About_Equal_Opportunity/Why_EO_Makes_Business Sense/Five_Ways_EO_Boosts_Profitability.asp Accessed 4 August.

EOWA (2006e), "Why Equal Opportunity Matters", http://www.eeo.gov.au/About_Equal_Opportunity/Why_Equal_Opportunity Matters.asp Accessed 4 August.

French, Erica and Glenda Strachan (2007), "Equal Opportunity Outcomes for Women in the Finance Industry in Australia: Evaluating the Merit of EEO Plans", Asia Pacific Journal of Human Resources, forthcoming.

Goward, Pru, Tania Mihailuk, Sally Moyle, Karen O'Connell, Natasha de Silva, Sarah Squire, Jo Tilly (2005), Striking the Balance: Women, men, work and family, Discussion Paper, Human Rights and Equal Opportunity Commission, Sydney.

Grimshaw, Patricia, Marilyn Lake, Ann McGrath and Marian Quartly (1994), Creating a Nation, McPhee Gribble, Ringwood, Vic.

Hammond, Suzanne (2006), Forward to the Past: The escalator the gender equalityset to 'reverse' Community and Public Sector Union, http://www.psa.labor.net.au/news/files/Forward\%20to\%20the\%20Past\%20SH .pdf Accessed 4 August.

Hancock, Linda (1999), "Women's Policy Interests in the Market State" in Linda Hancock (ed.) Women, Public Policy and the State, Macmillan Education Australia, Melbourne, 3-19.

Hunter, Rosemary (1992), Indirect Discrimination in the Workplace, Federation Press, Sydney.

ILO (2004), “The 'family friendly' workplace”, Information Sheet number WF-3, www.ilo.org/public/english/protection/condtrav/pdf/infosheets/wf-3.pdf . Accessed 4 August 2006.

IRC NSW (Industrial Relations Commission of New South Wales) (1998), Pay Equity Inquiry: Report to the Minister, 2 vols. Matter No. IRC 6320 of 1997.

IRC NSW (2000), Equal Remuneration Principle, Statement of Full Bench, NSWIRComm 116. Date of decision 30 June.

IRC NSW (2002), Crown Librarians, Library Officers and Archivists Award Proceedings - Applications under the Equal Remuneration Principle, Re [2002] NSWIRComm 55. File nos IRC 6304 of $2000 \&$ 2242, 2243, 3239 of 2001. Date of judgment 28 March. 
IRC NSW (2006), Miscellaneous Workers Kindergartens and Child Care Centres \&c (State) Award, re [2006] NSWIRComm 64. File nos IRC $5757 \& 6500$ of 2004. Date of judgment 7 March.

Kandola, Rajvinder and Johanna Fullerton (1994), Managing the Mosaic - Diversity in Action, IPD, London.

Kirton, Gill and Anne-marie Greene (2005), The Dynamics of Managing Diversity: A Critical Approach, $2^{\text {nd }}$ edn, Elsevier, Oxford.

Kramar, Robin (1998), "Managing Diversity: Beyond Affirmative Action in Australia", Women in Management Review, vol. 13, no. 4, 133-142.

Lake, Marilyn (1999), Getting Equal: The history of Australian feminism, Allen and Unwin, Sydney.

Lewis, Suzan (1997), “ 'Family Friendly’ Employment Policies: A Route to Changing Organizational Culture or Playing About at the Margins?", Gender, Work and Organization, vol. 4, no. 1, 13-23.

Liff, Sonia (1999), "Diversity and equal opportunities: room for a constructive compromise?" Human Resource Management Journal, vol 9, no. 1, 65-75.

Liff, Sonia (1997), "Two routes to managing diversity: individual differences or social group characteristics", Employee Relations, vol. 19, no. 1, 11-26.

Liff, Sonia and Ivy Cameron (1997), "Changing equality cultures to move beyond 'women's problems' ", Gender, Work and Organization, vol. 4 no.1, 35-46.

Neave, M. (1992), "From difference to sameness - law and women's work", Melbourne University Law Review, vol. 18, 768-807.

OECD (2002), Babies and Bosses: Reconciling Work and Family Life (Vol. 1): Australia, Denmark, The Netherlands, OECD, Paris.

Ostenfeld, Shane and Glenda Strachan (1999), "Women's Work and the Howard Government: The Impact of Social Conservatism on Australian Industrial Relations", Policy, Organisation and Society, vol. 18, 16-38.

Peetz, David (2006), Brave New Work Place: How Individual Contracts are Changing Our Jobs, Allen and Unwin, Sydney.

Poiner, Gretchen and Sue Wills (1991), The Gifthorse: A critical look at Equal Employment Opportunity in Australia, Allen and Unwin, Sydney.

Prasad, Pushkala, Judith K. Pringle and Alison M. Konrad (2006), "Examining the Contours of Workplace Diversity: Concepts, Contexts and Challenges", in Alison M. Konrad, Pushkala Prasad and Judith K. Pringle (eds), Handbook of Workplace Diversity, Sage, London, 1-22.

Probert, Belinda (2005), "Farewell to the 'fair go': Howard's 'vision' ", Evatt Foundation, http://evatt.labor.net.au/publications/papers/149.html Accessed 19 April 2006.

Queensland IRC (Industrial Relations Commission) (2002), Equal Remuneration Principle. The Queensland Council of Unions and Others AND Queensland Chamber of Commerce and Industry Limited, Industrial Organisation of Employers and Others (No. B450 of 2002). Date of decision 29 April.

Rafferty, Felicity (1994), "Equal Pay: The Evolutionary Process 1984-1994”, Journal of Industrial Relations, vol. 36, no.4, 451-467.

Ronalds, Chris (1988), Principles of Affirmative Action and Anti-Discrimination Legislation, Affirmative Action Agency Monograph No. 1, Ambassador Press, Sydney.

Ryan, Edna and Anne Conlon (1989), Gentle Invaders: Australian Women at Work, $2^{\text {nd }}$ edn, Penguin, Melbourne. 
Sappey, Richard, John Burgess, Michael Lyons and Jeremy Buultjens (2006), The New Federal Workplace Relations System, Pearson Education Australia, Sydney.

Sawer, Marian (2004), "The Commonwealth Sex Discrimination Act: Aspirations and Apprehensions", Women, Work and Equity Forum, August 2004, www.hreoc.gov.au/sex_discrimination/20thanniversary/women_work_equity/ speeches Accessed 5 April 2006.

Scutt, Jocelynne (1990), Women and the Law, Law Book, Sydney.

Short, Christine (1986) Equal Pay - What Happened? Journal of Industrial Relations, vol. 28 , no. 3, 315-335.

Sinclair, Amanda (2006), "Critical Diversity Management Practice in Australia: Romanced or Co-Opted?" in Alison M. Konrad, Pushkala Prasad and Judith K. Pringle (eds), Handbook of Workplace Diversity, Sage, London, 511-530.

Singh, Val, Susan Vinnicombe, Gianni Schiuma, Mike Kennerley and Andy Neely (2002), Diversity Management: Practices, Strategy and Measurement, Report by The Centre for Developing Women Business Leaders and The Centre Business for Performance, Cranfield School of Management, Cranfield University, England.

Strachan, Glenda and John Burgess(2000), "W(h)ither Affirmative Action Legislation in Australia?” Journal of Interdisciplinary Gender Studies, vol. 5, no. 2, 4663.

Strachan, Glenda and John Burgess (1998), "The 'family friendly' workplace: origins, meaning and application at Australian workplaces", International Journal of Manpower, vol. 19, no. 4, 250-265.

Strachan, Glenda, John Burgess and Anne Sullivan (2004), "Affirmative Action or Managing Diversity - What is the Future of Equal Opportunity Policies in Organisations", Women in Management Review, vol. 19, no. 4, 196-204.

Teece, Phil (2002), "Pay Equity for Library Workers in New South Wales", paper presented to LISS Conference, Adelaide. http://eprints.alia.org.au/archive/00000010/01/pay.equity.pdf Accessed 1 August 2006.

Thornthwaite, Louise (2002), "Work-Life balance: international research on employee preferences", ACIRRT Working Paper no. 79, University of Sydney.

Thornton, Margaret (2001), "EEO in a Neo-Liberal Climate", Journal of Interdisciplinary Gender Studies, vol 6, no. 1, 77-104.

Thornton, Margaret (1995), "The Cartography of Public and Private", in Margaret Thornton (ed.) Public and Private: Feminist Legal Debates, Oxford University Press, Melbourne, 2-16.

Thornton, Margaret (1990), The Liberal Promise: Anti-Discrimination Legislation in Australia, Oxford University Press, Melbourne.

Victorian Pay Equity Working Party to the Minister for Industrial Relations (2005), Report: Advancing Pay Equity - their future depends on it, http://www.business.vic.gov.au/busvicwr/_assets/main/lib60047/85_payequity-final-4-3-2005.pdf Accessed 1 August, 2006.

Webb, Janette (1997), "The Politics of Equal Opportunity", Gender, Work and Organization, vol. 4, no. 3, 159-169.

Whitehouse, Gillian (2004), "Pay Equity - 20 Years of Change and Continuity", Human Rights and Equal Opportunity Commission, http://www.hreoc.gov.au/sex_discrimination/20thanniversary/women_work_e quity/speeches/whitehouse.html Accessed 12 April 2006. 
Watson, Ian, John Buchanan, Iain Campbell and Chris Briggs (2003), Fragmented Futures: New Challenges in Working Life, Federation Press, Sydney.

Wirth, Linda (2001), Breaking through the Glass Ceiling: Women in Management, International Labour Office, Geneva. 